\title{
Influence of Organizational Climate on Job Satisfaction in Bosnia and Herzegovina Companies
}

\author{
Zijada Rahimic ${ }^{1}$ \\ ${ }^{1}$ School of Economics and Business, University of Sarajevo, Bosnia and Herzegovina \\ Correspondence: Zijada Rahimić, School of Economics and Business, University of Sarajevo, Trg Oslobođenja \\ Alija Izetbegović 1, 71000 Sarajevo, Bosnia and Herzegovina. Tel: 387-33-275-998. E-mail: \\ zijada.rahimic@efsa.unsa.ba
}

Received: December 3, 2012

Accepted: December 27, 2012

Online Published: January 25, 2013

doi:10.5539/ibr.v6n3p129

URL: http://dx.doi.org/10.5539/ibr.v6n3p129

\begin{abstract}
The aim of this paper is to analyze the importance and impact intensity of different dimensions of organizational climate in terms of satisfaction, and thus employee motivation and performance in companies across Bosnia and Herzegovina $(\mathrm{BiH})$. A particular challenge in this paper was to investigate whether there are differences in the importance of certain dimensions of organizational culture for job satisfaction of male and/or female participants, as well as differences in relation to the position in the organizational hierarchy. This paper examines the hypothesis that employees on the top of the organizational hierarchy have a more positive opinion about the organization. Organizations that take steps to monitor and control the organizational climate directly or indirectly exert influence on the efficiency and productivity, as well as the capacity for innovation and job satisfaction, but also and other attitudes towards the work of its employees. The research on the effect of organizational climate on job satisfaction in $\mathrm{BiH}$ is essential, notably in terms of BiH's specific business enviroment which dwells in a transition period and under complicated political and economic systems.
\end{abstract}

Keywords: organizational climate, job satisfaction, motivation, employment, efficiency

\section{Introduction}

In today's turbulent and dynamic environment, the ultimate development and survival of a company depends on the knowledge, skills and capabilities of its employees; on the other hand, both depend even more on directing those skills and knowledge towards reaching company's goals. Only a satisfied employee will be dedicated to his/her work, demonstrate creativity and aim towards meeting the needs and wishes of company's customers. Thus, in today's times of fierce global competition, almost all companies seek the opportunity to increase staff commitment and direct them (the staff) towards achieving company's objectives. For company's managers, this means employing classical as well as motivational measures in the process of staff motivation.

Employee satisfaction and motivation represent the main principles of contemporary human resources management, since only through quality motivation systems can a company increase its competitive advantage and value. Previous concepts of motivation schemes are becoming insufficient and ineffective, and it is, therefore, indispensable to develop and introduce new ones; their elaboration and versatility will greatly contribute to employee satisfaction and increase their performance.

This study asks how organizational climate can contribute to the increase in employee satisfaction, motivation and work commitment. In searching for the answer to this question, the paper will examine the significance of workplace satisfaction and motivation for company success. Furthermore, the theoretical section of this work will draw upon the characteristics of the organizational climate and the results of present-day research on the effects of organizational climate and culture on company success. In the second part of the paper, key dimensions of the organizational climate form the basis for the empirical research on staff satisfaction in companies in Bosnia and Herzegovina. Finally, the study concludes with the analysis of basic theoretical and empirical researches, as well as recommendations for measuring, analyzing and managing the organizational climate with the aim of increasing employee satisfaction or creating a positive climate for higher motivation levels, which, in turn, contribute to sustainable competitive advantages of a company.

\subsection{Organizational Climate and Culture as Intangible Motivation Strategies}

The motivational system, as a system of factors which influence individual behavior in the workplace (but also 
outside), includes development and application of various motivation strategies used to reach individual and business goals. Hence, we can talk about material compensation on one hand, and non-material stimulation on the other. Material compensation is a relatively complex system of different motivation forms directed at assuring and ameliorating employees' financial situation. On the other hand, non-material stimulation aims at meeting employees' needs; here the reasoning is that the more of employees' needs are met, the bigger their motivation will be. Thus, with the aim of creating comprehensive motivation systems, companies can opt for the organizational culture, job design, management style, employee inclusion, flexible working hours, awards, performance reviews, staff training, career development plans, just to name a few (Rahimić, 2010). "There are many similarities between organizational climate and culture although a number of researches have considered and rejected the proposition that they are synonymous. Yet, because the two variables share a number of overlapping attributes the distance between culture and climate is perhaps not so great as first thought" (McMurraym, 2003, p. 2). Therefore, this part of the paper will focus on the terminology of organizational culture and climate. Company culture is the basic system of values which explains behavioral norms, ways of thinking and employee performance on all levels (within a company). Company culture is based on common beliefs, which significantly influence the process of thinking and acting, as well as employees' feelings; it also shows what a typical company really is, and is used by management and their associates as a sort of a mental map. Although, there is no single definition of culture, the analysis of many different definitions demonstrates several similarities. For example, according to Kroeber et al. (1952, p. 155) culture is "the configuration of learned behaviour"; Pettigrew (1979, p. 574) "Culture is the system of such publicly and collectively accepted meanings operating for a given group at a given time" and according to Schein (1983, p. 14) "Organizational culture, then, is the pattern of basic assumptions that a given group has invented, discovered, or developed in learning to cope with its problems of external adaptation and internal integration - a pattern of assumptions that has worked well enough to be considered valid and, therefore, to be taught to new members as the correct way to perceive, think, and feel in relation to those problems". Armstrong (1990) outlines three basic elements of organizational culture, including: organizational values, organizational climate and management style. In simple terms, organizational climate can be considered as an integral part of the working milieu, which, in turn, is the consequence of organizational culture (manifestation of values, norms, opinions and beliefs, customs and rituals, language and symbols) (Buble, 2010, p. 208). "Climate is the sum of the effects of culture as perceived by the individual" (Gray, 2001, p. 105). "Organizational climate has been defined as employees' perceptions of the events, practices, and procedures and the kinds of behaviors that are rewarded, supported and expected. Organizational climate therefore deals with the perceptions of employees regarding important work-related aspects of the organizations values. Organizational climate has been demonstrated to have a strong influence on individual and group behavior within an organization" (Wei \& Morgan, 2004, p. 378).

Among the authors who defined organizational climate, there is no single agreement regarding its conceptual classification. Two basic approaches to the definition of organizational climate exist: the objective and the realist approach which argue that, objectively, climate exists as part of organizational reality, and that subjectively climate is defined according to individual perception of organization's members, which are, in turn, influenced by the effects of organization's characteristics and individuals. Previous research on organizational climate describes it as an objective characteristic of an organization (James \& Jones, 1974, Forehand \& Gilmer, $1964 ; \ldots)$, while modern-day studies define it as a set of opinions, feelings and behaviors which characterize each company (Schneider \& Hall, 1972; James \& Sells, 1981; ...). In this work, organizational climate is observed as a reflex on perception and descriptive believes about the organizational environment.

Organizational climate has a long history in the field of industrial and organizational psychology. It was in the 1920s, as part of the Human Relations movement, that programs for maintaining good interpersonal relationships and creating positive working climate were created. Organizational climate was first mentioned in 1939 (Lewin, Leppitt and White), while organizational climate is mentioned in Petigrew's article from 1979. Many scientists and consultants researched the concept of organizational culture, notably during the time of hardships, when companies confronted external crisis or made management errors. Since then, many scientists and consultants worked on the issue of organizational culture, but did so mainly during times of extreme crisis and management errors. Hence, during the economic crisis in the mid-1970s and the beginning of 1980s, many published works made a connection between the cultural aspects of a company and its success. During this period, Western companies were surmounted by ambitious Japanese competitors, who introduced new production methods. Moreover, their unusual company culture continued to set new productivity records. McKinsey consultants, Tom Peters and Robert Waterman, did an intensive research on Japanese challenges. During the 1970s, these researches resulted in the establishment of the so called "7-S Model". The central variables of the "7-S Model" were precisely the common values of two distinct company cultures (Peters \& Waterman, 2000). The differences 
between American and Japanese company cultures were also studied by an American management professor, William G. Ouchi. He published his research results in 1981, in a book entitled "Theory Z: How American Management Can Meet the Japanese Challenge?"

An important scientific contribution on the subject was also made by a Dutch scientist, Geert Hofstede. At the beginning of 1980s he published the results of his research conducted between 1967 and 1978 at the IBM. The research included 116.000 associates and managers on all levels. Hofstede showed that there are national and regional cultural groups which influence managers' behavior, as well as the entire process of company organization and management. According to Hofstede, the values that form the basis of a particular culture remain invisible and unknown. Organizational psychologist Edgar Schein of the Massachusetts Institute of Technology shares Hofstede's opinion. He divides company culture into three different levels: artifacts (i.e. visible processes and structure), values and understandings. In his works published between 2003 and 2006 he shows that company rituals, logos and trademarks are visible and easy to change. However, perceptions which form the basis of all values are invisible, hard to reach and difficult to change. At the beginning of 2000s, Schein's model was expanded by Sonja Sackmann, a Professor of organizational psychology from Munich. She went on by establishing additional categories: behavioral norms and values (accepted and demonstrated). It is exactly these behavioral norms, values and understandings that significantly determine the type of communication, problem solving, decision-making, conflict management, learning processes and motivation (Leitl \& Sackmann, 2010). Taking into account the definition and characteristics of organizational climate, one can say that organizational climate, directly or indirectly, influences productivity, innovation and employee satisfaction.

\subsection{The Significance of Organizational Climate and Culture for Company Success}

Climate significantly influences organizational and psychological processes of communication, problem solving, learning, motivation, efficiency and productivity of an organization, as well as innovation and job satisfaction. Therefore, climate is becoming the focus of organizational experts, notably because of a growing number of empirical data that proves the fact that good organizational climate boosts productivity and efficiency and increases employee satisfaction. Numerous researches are trying to examine the relationship between organizational climate and company success. In 1973, Pritchard and Karisick proved that climate is connected to departmental success (within a company), as well as to employee satisfaction. Ekvall (1987) refers to his earlier research in which climate of a successful department was characterized by higher scores in the following dimensions: challenge, support of new ideas, freedom and dynamics, and trust/openness. Patterson et al. (2004) confirmed a positive correlation of several aspects (i.e. concern about employee's well-being) of climate and company productivity on a sample of 42 companies. Research studies conducted by Rose et al. (2002 and 2004) show a strong bond between organizational climate and employee reaction to commitment and organizational process, as well as their attitudes towards apsentism. Through her research, Heidi Bushel (2007) came to a conclusion that the organizational climate model by Hart et al. (1996) explains around 16\% of one-day sick leaves and $10 \%$ of various other absences. Other studies support the relationship between organizational climate and many other factors, such as job satisfaction, health, creativity, innovation and change. Jaeger, Bedell and Mumford (2007) assessed the relationship between climate and creativity.

The failure of many re-engineering processes that occurred in the 1990s can be explained by company's insufficient organizational culture. Hence, numerous scientific researches were conducted, all with the purpose of confirming the relationship between company culture and success. In 1992, two Harvard professors, John Kotter and Jim Heskett presented the results of an 11 year annual comparison between more successful and less successful companies. They showed that firms with strong company culture (concentrated on buyers, business partners, management and owners) can increase their profits by $56 \%$, while companies with weak company culture can augment their earnings only by $1 \%$. Furthermore, the research initiated by the Bundesministerium fuer Arbeit und Soziales (German Ministry of Labor and Social Issues) showed that a combination of cultural dimensions (identification, team orientation, career development support, fair employee relations and ability to reorganize) can explain up to $31 \%$ of company's financial success. Here, culture notably influences the process of hiring associates, innovation levels and subjective feelings of stress. The reasons for which highly qualified workers leave the company are also connected to company culture, up to 32\% (Leitl \& Sackmann, 2010, p. 39).

Regardless of research results, the top company management did not pay a lot of attention to this issue; in turn, decisions were made on the basis of quantitative indicators. Today, the situation is different. According to the research conducted in Germany in 2009, out of 157 managers, $45 \%$ stated that company culture is very important for success, while $24 \%$ said that it is extremely important for success. It is believed that these different views are 
influenced by rapid economic crisis. Moreover, the data shows that company culture, despite financial and economic crisis, can be viewed as an essential (basic) success factor, and maybe even more so than before (Leitl \& Sackmann, 2010, pp. 40-41). The significance of company culture will increase in the future. The increased importance of company culture rests on the fact that organizational cultures cannot be copied, because they are invisible and deeply imbedded into company's structure. Hence, the comparison between company's own culture and the culture of its competitors is difficult to make. When comparing two distinct company cultures, it is possible to use information such as: the operative way of workers' behavior, workplace equipment, stories and anecdotes about the company, etc. However, it is important to note that this process must be continuous. If results show that company culture of a certain firm is stronger and deeper in comparison to its competitors and field average, then this will indicate future flexible accommodation to changes on behalf of those competitors. It is only through positive measures that help shape knowledge and motivation that company culture contributes to its competitiveness.

Managers can influence organizational climate in short and medium terms, but only when climate changes in the long run does culture change as well (usually in the period of five years). Therefore, in the short and medium run (up to five years) management might deal with organizational climate (and indirectly also culture), which is, in fact, the main factor of efficiency. The work of the management is directly aimed at climate, and indirectly also at culture, because through influencing climate (which is closely linked to success and satisfaction), they can also influence culture.

\section{Empirical Research on Organizational Climate and Job Satisfaction in Companies in Bosnia and Herzegovina}

Organizational climate can be measured by a number of objective and subjective indicators. Previous research on organizational climate describes it as an objective characteristic of an organization, while modern-day studies define it as a set of opinions, feelings and behaviors which characterize each company. The distinction between objective and subjective measures is mirrored in the two theoretical approaches to the definition of organizational climate (Ekvall, 1987). In this work, organizational climate is observed as a reflex on perception and descriptive believes on organizational environment (ambiance). The purpose of this study was to analyze the significance and the intensity of various dimensions of organizational climate on job satisfaction and employee motivation. Through data analysis, this work examines the hypothesis that employees on the top of the organizational hierarchy have a more positive opinion about the organization. Employee opinion could be considered a significant guideline to company managers in Bosnia and Herzegovina, notably in the process of decision-making and strategic planning, but most importantly during changes in business policies and creation of future plans in regards to human resource management.

\subsection{Sample Group}

This research encompassed 111 employees from production oriented companies and different industrial sectors: food, textile, wood and machine industries. These industries are traditional and typical for Bosnia and Herzegovina. The research was conducted through surveys, using random sampling method. In the first part of the survey, the examinees provided some general data on gender, age, education level and their position within the company, while the second part of the survey dealt with different dimensions of organizational climate (statements which describe different situations in the organization - events, conduct, rules, relations). The third part of the questionnaire examined employee satisfaction in terms of the existing motivational factors in their respective companies. The answers were ranked on a scale from 1 to 5 , with a higher number denoting a higher level of agreement with a certain statement.

The sample group is dominated by males (75\%), which can be explained by looking at companies' activities and the field in which they operate (industrial). Women were represented by only $39.20 \%$, which indicates lower female presence in the organizational structure. More specifically, in the food industry there were $35.40 \%$ females, while they were represented by $68.8 \%$ in the textile, $13.53 \%$ in the wood and $16.77 \%$ in the machine industries. Moreover, high unemployment rates among women in Bosnia and Herzegovina is a significant problem and a topic of many discussions, roundtables and NGO activities (Statistical Yearbook, 2011, pp. 108-112). When looking at education levels, the highest number of employees are skilled workers (44\%) and highly-skilled/secondary education workers (35\%), followed by employees with university degrees or two years of secondary education $(10 \%)$, and lastly semi-skilled workers $(1 \%)$. The highest number of examinees is employed in the production sector (87\%), followed by administration (11\%) and management $(2 \%)$. The sample group is heterogeneous according to education levels (see Table 1). The following table also shows the examinees' position in the organizational hierarchy. 
Table 1. Educational level and examinees' position in organization

\begin{tabular}{llll}
\hline Educational Level & Percentage & Position held within the company & Percentage \\
\hline Semi-skilled and 2 years of secondary education & $11 \%$ & Production worker & $87 \%$ \\
Skilled worker & $44 \%$ & Administration & $11 \%$ \\
Highly-skilled worker and secondary education & $35 \%$ & Management & $2 \%$ \\
University education & $10 \%$ & & \\
\hline
\end{tabular}

Source: Authors' calculation.

Age structure is the following: $1 \%$ up to 20 years, $38 \%$ between 21 and 30 years, $19 \%$ of employees aged between 31 and 40 years. A significant number of employees, or more precisely $34 \%$ are between $42-50$ years of age while 51 years and over was represented $8 \%$ of associate-respondents.

\subsection{Key Characteristics of the Organizational Climate of Companies in Bosnia and Herzegovina}

The intention was to measure the organizational climate according to 24 criteria, or, more precisely, 24 statements. The basis for defining the criteria of this study lies in a specific way of looking at the organizational culture, which represents a reflection on the perception and descriptive beliefs of the employees regarding the atmosphere in their companies. In testing the organizational climate, the following categories were taken into consideration: perception on the quality of work, products and services, sense of belonging to the organization, structural organization, way of management, company's presence and awareness about its existence, company's aims and visions, communication and information, interpersonal relations, employee qualifications, possibilities for additional education, awards and motivation. For every answer (statement) we counted the average and standard deviation, which shows single answers that depart from the average. The lower the standard deviation the more similar answers were recorded among the examinees (more homogenous answers).

Table 2. Descriptive statistics for the analyzed dimensions and derived constructs

\begin{tabular}{llll}
\hline No & Dimension & Average & Stand. dev. \\
\hline 1. & I feel responsible for the quality of my work & 4.712 & 0.706 \\
2. & My department has a clear set of standards and quality goals & 4.229 & 1.094 \\
3. & I am aware of the fact that changes in the organization are important & 4.153 & 1.105 \\
4. & I am ready to take the risk of introducing my own initiatives and innovations & 4.084 & 1.175 \\
5. & Our organization has relatively high expectations in regards to work success & 3.936 & 1.219 \\
6. & Good work results are readily noticed and awarded & 2.883 & 3.204 \\
7. & Outside of work, I speak positively of my organization & 3.811 & 1.311 \\
8. & In case my salary was lowered due to business problems, I would not leave the organization & 3.398 & 1.472 \\
9. & The organization offers good training which I need to successfully complete my tasks & 3.306 & 1.256 \\
10. & The training system is good & 3.135 & 1.338 \\
11. & We cooperate very well in our organization & 3.523 & 1.174 \\
12. & I help other people & 4.477 & 0.903 \\
13. & I accept my organization's goals as if they were my own & 4.382 & 0.938 \\
14. & Policies and goals of my organization are clear to me & 3.706 & 1.328 \\
15. & I have a clear picture of what is expected of me & 4.367 & 1.094 \\
16. & My tasks and responsibilities are clearly defined & 4.139 & 1.063 \\
17. & My seniors discuss my performance with me & 2.972 & 1.494 \\
18. & My seniors accept argumented objections regarding their work & 2.727 & 1.387 \\
19. & The organization adequately forwards information & 3.315 & 1.307 \\
20. & I feel responsible for providing information in a timely manner, but also receiving it & 3.955 & 1.176 \\
21. & Career advancement criteria is clear to me & 3.227 & 1.463 \\
22. & I have equal opportunities for advancement on all levels & 2.881 & 1.419 \\
23. & Underperformance and weak results are reprimanded & 3.455 & 1.482 \\
24. & Employees who have more responsibilities are awarded more often & 2.216 & 1.391 \\
& Organizational climate & 3.652 & 0.830 \\
\hline
\end{tabular}

Source: Authors' calculation.

The highest average grade was given to the statement that affirms the responsibility of employees for the quality of their work (4.712). The clarity of company's goals is also notable - "I have a clear picture of what is expected of me" - (4.367). An important factor in reaching company's objectives is certainly mirrored in the statement 
that employees accept their company's standards as their own (4.367), that they have clear expectations of their work (4.367), as well as that their department has a clear set of standards and quality goals (4.229).

Statements which relate to work results and "employee-manager" relations are especially alarming. The statement "good work results are readily noticed and awarded" received a low grade of 2.883 . However, the standard deviation of 3.204 shows that there are significant deviations in employees' opinions. The lowest average grades were given to the following statements: I discuss my performance with my seniors (2.727), I have equal opportunities for advancement on all levels (2.881), and employees who have more responsibilities are awarded more often (2.216).

In order to review the methods and group affinity of the above statements, a factor analysis was conducted. The adequacy of using factor analysis was verified through the use of sample correlation matrix (Table 3). Considering the fact that in the correlation matrix each dimension is emphasized by at least one coefficient which is higher than 0.3 , the use of factor analysis is justified. The method of factor analysis which is used represents the analysis main components.

Table 3. Model with extracted factors - with rotation

\begin{tabular}{llll}
\hline Component & Total & \% Variants & Cumulative \% \\
\hline 1 & 6.309 & 26.286 & 26.286 \\
2 & 6.003 & 25.012 & 51.298 \\
3 & 1.679 & 6.997 & 58.296 \\
4 & 1.605 & 6.690 & 64.985 \\
\hline
\end{tabular}

Source: Authors' calculation.

The achieved solution explained $64.985 \%$ of the overall variability. This is acceptable, since the bottom border of acceptance cumulates to $50-60 \%$ of the variance explained by the resulting factors. In the rotated solution, four factors satisfy both criteria: the inherent value and the percentage of the overall variant. The first factor explains $26.29 \%$ of the overall variability between variants, the second factor justifies $25.01 \%$, the third one clarifies $7.0 \%$, and lastly the fourth one accounts for $6.69 \%$ of the overall variant (Table 4 ).

Table 4. Overview of the four identified groups of factors

\begin{tabular}{|c|c|}
\hline $\begin{array}{l}\text { tors: } \\
\text { onsibility for the quality of work performance, }\end{array}$ & $\begin{array}{l}\text { 2nd group of factors: } \\
\text { Job qualifications, career advancement and conversation } \\
\text { about work efficiency }\end{array}$ \\
\hline $\begin{array}{l}\text { - I feel responsible for the quality of my work. } \\
\text { - My department has a clear set of standards and quality goals. } \\
\text { - I am aware of the fact that changes in the organization are } \\
\text { important. } \\
\text { - I am ready to take the risk of introducing my own initiatives and } \\
\text { innovations. } \\
\text { - Our organization has relatively high expectations in regards to } \\
\text { work success. } \\
\text { - I help other people. } \\
\text { - I accept my organization's goals as if they were my own. } \\
\text { - Policies and goals of my organization are clear to me. } \\
\text { - I have a clear picture of what is expected of me. } \\
\text { - My tasks and responsibilities are clearly defined. } \\
\text { - I feel responsible for providing information in a timely manner, but } \\
\text { also receiving it. }\end{array}$ & $\begin{array}{l}\text { - The organization offers good training which I need to } \\
\text { successfully complete my tasks. } \\
\text { - The training system is good. } \\
\text { - We cooperate very well in our organization. } \\
\text { - My seniors discuss my performance with me. } \\
\text { - My seniors accept argumented objections regarding their } \\
\text { work. } \\
\text { - The organization adequately forwards information. } \\
\text { - Career advancement criteria is clear to me. } \\
\text { - I have equal opportunities for advancement on all levels. } \\
\text { - Employees who have more responsibilities are awarded more } \\
\text { often. }\end{array}$ \\
\hline $\begin{array}{l}\text { 3rd grouI } \\
\text { Loyalty }\end{array}$ & $\begin{array}{l}4 \text { th grou } \\
\text { Factors }\end{array}$ \\
\hline $\begin{array}{l}\text { - In case my salary was lowered due to business problems, I would } \\
\text { not leave the organization } \\
\text { - Underperformance and weak results are reprimanded }\end{array}$ & $\begin{array}{l}\text { - Good work results are readily noticed and awarded } \\
\text { - Outside of my workplace, I speak positively of my } \\
\text { organization }\end{array}$ \\
\hline
\end{tabular}

Source: Authors' calculation.

It is obvious that the factor analysis is a very useful multivariational statistical technique used to effectively 
extract information from large databases, or when analyzing multiple factors. Also, this technique demonstrates interesting relations, which might not be obvious from analyzing raw data or even the correlation matrix.

Alongside the analysis of key characteristics of the organizational climate, a special challenge was to evaluate the opinions of different categories of examinees, or better their vision of the work environment. In order to test the differences between median values of male and female opinion, the Mann-Whitney test was used, since the distribution of the analyzed variable does not meet the "normality" condition. The value of "P", together with appropriate statistical tests, is considered statistically important or significant if it is lower than 0.05 , since tests are done with first level mistakes of $5 \%$, or $95 \%$ significance. In this case, the hypothesis that the observed sample or groups are statistically significantly different is accepted.

When comparing the answers given by males and females, there is a significant difference only in relevance only to the statement: "policies and goals of my organization are clear to me" ( $\mathrm{z}$ (Note 1) $=-2.325, \mathrm{p}=0.02>0.05$ ). According to this dimension, the male population gave an average grade of 3.83 , while females marked it significantly lower, with only 2.7 . This grade creates a need for an additional question that could be researched in the future, and that is the participation of female population in decision-making and goal-setting procedures, as well as career advancement and development opportunities offered to them.

Unlike the similar results given by males and females, the views on organizational climate are quite dispersed on different organizational levels.

Table 5. Overview of organizational climate at different organizational levels

\begin{tabular}{|c|c|c|c|c|c|c|c|c|c|c|}
\hline \multirow{2}{*}{$\begin{array}{l}\text { Statistical parameters } \\
\text { Organizational level }\end{array}$} & $\mathrm{N}$ & Average & \multirow[t]{2}{*}{$\begin{array}{l}\text { Stand. } \\
\text { dev. }\end{array}$} & $\mathrm{N}$ & Average & \multirow[t]{2}{*}{$\begin{array}{l}\text { Stand. } \\
\text { dev. }\end{array}$} & $\mathrm{N}$ & Average & \multirow[t]{2}{*}{$\begin{array}{l}\text { chi-squared } \\
\text { (Note 2) }\end{array}$} & \multirow[t]{2}{*}{$\begin{array}{l}\mathrm{P} \\
\text { Value }\end{array}$} \\
\hline & \multicolumn{2}{|c|}{ Production } & & \multicolumn{2}{|c|}{ Administration } & & \multicolumn{2}{|c|}{ Management } & & \\
\hline The training system is good & 95 & 3.042 & 1.352 & 12 & 4.000 & 0.739 & 1 & 5.000 & 7.564 & 0.023 \\
\hline $\begin{array}{l}\text { My tasks and responsibilities } \\
\text { are clearly defined }\end{array}$ & 92 & 4.207 & 1.075 & 12 & 3.583 & 0.900 & 1 & 4.000 & 6.054 & 0.048 \\
\hline $\begin{array}{l}\text { I discuss my performance with } \\
\text { my seniors }\end{array}$ & 92 & 2.761 & 1.448 & 12 & 4.500 & 0.798 & 1 & 5.000 & 16.915 & 0.000 \\
\hline $\begin{array}{l}\text { My seniors accept argumented } \\
\text { objections regarding their work }\end{array}$ & 94 & 2.521 & 1.334 & 12 & 4.167 & 0.718 & 1 & 5.000 & 17.115 & 0.000 \\
\hline $\begin{array}{l}\text { The organization adequately } \\
\text { forwards information }\end{array}$ & 95 & 3.211 & 1.352 & 12 & 4.083 & 0.669 & 1 & 5.000 & 6.471 & 0.039 \\
\hline $\begin{array}{l}\text { I feel responsible for providing } \\
\text { information in a timely } \\
\text { manner, but also receiving it }\end{array}$ & 94 & 3.840 & 1.212 & 12 & 4.750 & 0.452 & 1 & 5.000 & 7.940 & 0.019 \\
\hline
\end{tabular}

Source: Authors' calculation.

Through the analysis of these data, a significant difference in marks given by production workers and management (administration and management) was noticed. Therefore, companies in Bosnia and Herzegovina also confirmed that organizational climate is graded differently, more precisely according to the level of organizational status. The higher the status of an employee in the organizational hierarchy, the more positive their opinion about the organization (3.5:4.3). This result confirms the initial hypothesis. The original dimensions in which there is a significant statistical difference between the grades given by different organizational levels are illustrated in table 2. (see no: 10,16,17, 18, 19 and 20). Out of 24 statements concerning organizational climate, six (6) demonstrate significant deviations in terms of opinions given by employees from different categories. According to Kruskal-Wallis non-parametric test, the value of ,p” is lower than 0.05 , which means that there is a significant difference in grades given by production workers, administration and management. All the other criteria (out of 24 total) received similar grades, and there are no considerable deviations. Therefore, it is obvious that the highest grades were given by those employed in the management, followed by administration workers, while the lowest grades were given by those employed in the production sector. It is interesting to note that production workers consider their work duties to be clearly defined. However, this is not the case with administration workers. This means that employees in the administrative sector do not have clear work guidelines, nor do they know what is expected of them. In the future, this could be a signal to company's management, which would certainly help in defining specific work tasks, notably in the process of workplace systematization and hiring. 
When it comes to "employee-manager" relations, the lowest grade was given by production workers. The statement "I discuss my performance with my seniors" received only 2.761 from production workers, 4.5 by administrative workers and an amazing 5.0 by management. Since only one examinee came from top management, the analysis of his grade is irrelevant, but it is interesting for the discussion. An even lower grade was given by production workers for the statement "My seniors accept argumented objections regarding their work" (2.521), while the administration graded this statement with 4.167. These grades demonstrate the existence of significant setbacks in the system of appraisal and assessment of employees, as the central activity of human resource management. The perceptions about the quality of communication also differ, based on the status in the organizational hierarchy. The average mark for the statement "the organization adequately forwards information" was 3.211 as graded by production workers, 4.083 by the administration and 5.0 by the management. This data shows that one-way, top-bottom communication is predominant. If we consider the fact that communication is the "bloodstream of every organization" and that in today's dynamic and unpredictable environment it is impossible "not to communicate", then we should give special attention to analyzing and improving communication in companies across Bosnia and Herzegovina. Training activities, as well as enhancement of communication skills of top management employees should be undertaken.

The goal of this research was to, aside from organizational climate, test the employee satisfaction. This study is just a part of a broader research, which alongside organizational climate also examined the levels of employee satisfaction. The following categories were measured: satisfaction with the co-workers, job security, workplace, working hours, senior management, training possibilities, status in the organizational hierarchy, management, workplace conditions, promotion possibilities and salary (Table 6).

Table 6. Descriptive statistics for the analyzed dimensions and derived constructs

\begin{tabular}{llll}
\hline No. & Dimension & Average & Stand. dev. \\
\hline 1. & I am satisfied with my co-workers & 3.766 & 1.191 \\
2. & I am satisfied with a secure workplace & 4.207 & 1.184 \\
3. & I am satisfied with the workplace & 3.757 & 1.491 \\
4. & I am satisfied with work hours & 4.092 & 1.266 \\
5. & I am satisfied with my seniors & 3.405 & 1.404 \\
6. & I am satisfied with qualification opportunities & 3.450 & 1.319 \\
7. & I am satisfied with my status in the organization & 3.333 & 1.337 \\
8. & I am satisfied with organization's management & 3.275 & 1.433 \\
9. & I am satisfied with work conditions (equipment, space, security measures) & 4.118 & 1.269 \\
10. & I am satisfied with advancement opportunities & 2.937 & 1.509 \\
11. & I am satisfied with my salary & 2.582 & 1.323 \\
& Employee satisfaction & 3.538 & 1.029 \\
\hline
\end{tabular}

Source: Authors' calculation.

The employees are concerned with job security (4.207), which is understandable considering high unemployment rates in Bosnia and Herzegovina, as well as recession. They are also satisfied with work conditions and working hours, while they are least satisfied with their salaries (2.582) and career advancement opportunities (2.937). The comparison between the average grade given to organizational climate (3.652) and employee satisfaction (3.538) was made using the non-parametric Wilcox ranking test. The value obtained was -1.745 , with "p" value of $0,081>0,05$. These results demonstrate that employees have a similar opinion of employee satisfaction and organizational climate.

We also analyzed the correlation between the examined dimensions. If we search for a relation between the average grade given to organizational climate and the average mark given to employee satisfaction, the correlation coefficient equals to 0.866 with a significant "p" value of 0.000 , which means that there is a direct correlation between the examined statements. The statistical analysis of the data and the method of simple correlation both show the effect which the organizational climate has on employee satisfaction. The degree of influence is 0.866 , which means that $86.6 \%$ of satisfaction level changes among all the employees are caused by changes in the organizational climate (employee perception of organizational climate dimensions). More precisely, organizational climate significantly influences employee satisfaction in companies across Bosnia and Herzegovina.

Taking into account the fact that satisfied and motivated employees are devoted to their jobs, and that they attain better results, as well as the data obtained through this research, one can come to a conclusion that organizational 
climate directly influences long-term company success. Therefore, the top management of companies in Bosnia and Herzegovina should give a great deal of attention to various elements of organizational climate, as well as human resource management activities (starting from job and workplace design, to continuous education and training, career development, use of award systems and various non-material motivation strategies).

\section{Conclusion}

This paper presents a research on the relationship between organizational climate and job satisfaction where organizational climate was observed as a non-material motivational strategy. Organizational culture is considered a non-material motivational strategy in theory and practice, while organizational climate is considered as one of the three basic elements of organizational culture (or an outcome of organizational culture). Organizational climate intercedes work and interpersonal relations, and influences the processes of communication, problem solving, learning, motivation and efficiency. In this paper, organizational climate was measured according to 24 criteria (statements). A hypothesis which states that employees who are positioned higher in the company hierarchy have more positive opinions about the organization. The research was performed on a sample of 111 employees from production companies of different industrial branches: food, textile, wood and machine industry. On the basis of data analysis, it was concluded that opinions and ranking of organizational climate in companies across Bosnia and Herzegovina also vary according to the level held in the hierarchical structure. Those employed in the higher management of the organizational hierarchy have more positive opinions about the organization (3.5:4.3), which confirms our research hypothesis. A statistically significant difference in the grades given by employees from different organizational levels exists on six criteria (statements) in the organizational climate.

Through the method of factor analysis of the 24 criteria of organizational climate, four categories were defined. They explain $64.99 \%$ of the overall variability. The first category is dominated by individual responsibility for the quality of work performance, support for change, and acceptance and goal reaching. This category explains $26.29 \%$ of the overall differences in variables. The second factor, which refers to job qualifications, career advancement and conversation about work efficiency accounts for $25.012 \%$ of the overall variability. The third factor (loyalty) explains only $6.997 \%$ of the overall variability, while the lowest level of variability $(6.69 \%)$ is accounted by the so called factors of compliments and positive attitudes.

Employee satisfaction was examined through 11 statements. It can be concluded that the employees are most satisfied with job security, while they are least happy with their salaries. It is obvious that top management attempts to avoid dismissing employees had motivational effects on BiH's business environment, which is characterized by high unemployment rates and recession. Lowering salaries and irregular payments had a negative effect on employee satisfaction. However, it can be concluded that job satisfaction is on a satisfactory level (3.538).

Through analyzing the correlation between organizational climate and job satisfaction, it was possible to conclude that organizational climate significantly influences job satisfaction, since the level of influence is 0.866. This means that $86.6 \%$ of all job satisfaction changes were influenced by changes in organizational climate.

Lastly, the correlation analysis clearly demonstrated that there is a significant direct relation between organizational climate and employee satisfaction, because the level of influence is 0.866 . This means that $86.6 \%$ of all changes in job satisfaction were caused by changes in organizational climate, which implies that organizational climate significantly influences employee satisfaction in companies in Bosnia and Herzegovina. Resting on the fact that satisfied and motivated employees obtain better results, we can conclude that organizational climate directly influences company success. Therefore, in order for a company to survive and advance in the future, management of organizational climate, which stems from strong organizational culture where co-workers function according to the optimum of their abilities, is essential for contributing to the overall value of every organization.

\section{References}

Armstrong, M. (1990). How to be an even better manager. London: Rogan page.

Buble, M. (2010). Utjecaj organizacijskih varijabli na uspjeh programa unapređenja poslovnih procesa. Split: Ekonomski fakultet Split.

Bushell, H. M. (2007). Quantitativbestimmung die Schluesselfuehrungsverhalten fuer das Verursachen einer erfolgreicher Kultur, die Angestellte bevollmaechtigt und organisatorische Leistung verstaerkt. Toronto, Kanada: Gesundheit und Arbeit u. Wellnes-Konferenz. 
Ekvall, G. (1987). The climate metaphor in organizational theory. Advances in Organizational Psychology: An International review, 177-190.

Forehand, G., \& Von Gilmer, B. (1964). Environmental variations in studies of organisational behaviour. Psychological Bulletin, 62, 362-381. http://dx.doi.org/10.1037/h0045960

Gray, R. (2001). Organisational Climate and Project Success. International Journal of Project Management, 19(2), 103-109. http://dx.doi.org/10.1016/S0263-7863(99)00060-5

Hart, P. M., Greif, M. A., \& Fassbinder, C. L. (1996). Handbuch fuer die QPASS uebersicht. Brisbane: Allgemeiner Sektor-Management Kommission.

Hofstede, G. (1980). Cultures Consequences: International Differences in Work-related values. Newbury Park: CA, Sage.

Jablin, F. M., Putnam, L. L., \& Roberts, K. H. (1989). Handbook of organizational Communication. Newbury Park-London-New Delhi: SAGE Publications.

Jaeger, S. T., Bedell, K. E., \& Mumford, M. D. (2007). Klima fuer Kreativitaet: Ein quantitativer Bericht. Kreativitaet-Forschung Journal, 19(1), 69-90.

James, L. R., \& Sells, S. B. (1981). Psychological climate: Theoretical perspectives and empirical research. In D. Magnusson (Ed.), Toward a psychology of situations: An interactional perspective (pp. 275-295). Hillsdale: Lawrence Erlbaum.

James, L., \& Jones, A. (1974). Organizational Climate: A review of theory and research. Psychological Bulletin, 12, 1096-1112. http://dx.doi.org/10.1037/h0037511

Kotter, J., \& Heskett, J. (1992). Corporate culture and performance. New York: The Free Press.

Kotter, J., \& Heskett, J. (1993). Die ungeschriebenen Gesetze der Sieger - Erfolgsfaktor Firmenkultur. Duesseldorf: Econ Verlag.

Kroeber, A. L., \& Kluckhohn, C. (1952). Culture: A Critical Review of Concepts and Definitions. Peabody Museum, Cambridge, MA.

Lammers, C. J., \& David, J. H. (Eds.). (1979). Organizations Alike and Unlike: International and Interinstitutional Studies in the Sociology of Organizations. London: Routledge \& Kegan Paul.

Leitl, M., \& Sackmann, S. (2010). Unternehmenskultur als Erfolgsfaktor. Harvard Business Manager, January, 36-45.

Lewin, K., Lippit, R., \& White, R. K. (1939). Patterns of Aggressive behaviour in experimentally created 'Social Climate'. Journal of Social Psychology, 10, 271-290. http://dx.doi.org/10.1080/00224545.1939.9713366

McMurray, A. J. (2003). The Relationship Between Organizational Climate and Organizational Culture. The Journal of American Academy of Business, 3, 1-7.

Ouchi, G. W. (1981). Teory Z: How American Management Can Meet the Japanese Challenge. Reading, MA: Addison Wesley.

Peters, T. J., \& Waterman, R. H. (2000). Auf der Suche nach Spitzenleistungen. Landsberg am Lech: MVG-Verlag.

Pettigrew, A. M. (1979). On Studying Organizational Cultures. Administrative Science Quarterly, 24, 570-581. http://dx.doi.org/10.2307/2392363

Pritchard, R. D., \& Karasick, B. W. (1973). The effect of organizational climate on managerial job performance and satisfaction. Organizational Behaviour and Human Performance, 9, 126-146. http://dx.doi.org/10.1016/0030-5073(73)90042-1

Rahimić, Z. (2010). Menadžment ljudskih resursa, Sarajevo, Ekonomski fakultet u Sarajevu.

Rose, D. M., \& Greif, M. (2002). Hohe Leistung Arbeit Systeme, Stunde Praxis und hohe Miteinbeziehung: Eine Gruppe Niveauanalyse. Akademie des Managements, Konferenz 2002, Denver, USA.

Rose, D. M., \& Waterhouse, J. M. (2004). Erfahren des neuen allgemeinen Managements: Angestelltreaktion auf flexible Arbeit Praxis und Leistungsüberwachung. Industrielle Beziehung- zwischen den Sozialpartnerneuropäische Konferenz, Utrecht, die Niederlande.

Rose, D. M., Douglas, M., Greif, M. A., \& Linsley, C. (2002). Bilden der Stunde Arbeit: Zusammenstellung Handhaben des Verhältnisses: Verpflichtung und Arbeit Wirksamkeit. Australisches menschliche 
Betriebsmittel-Institut Stunde übt Tag 2002. Brisbane, Australien.

Sackmann, S. (2004). Erfolgsfaktor Unternehmenskultur, Wiesbaden, Gabler. http://dx.doi.org/10.1007/978-3-322-82623-7

Sackmann, S. A. (2001). Cultural Complexity in Organizations: The Value and Limitations of Qualitative Methodology and Approaches. In C. L. Cooper, S. Cartwright \& P. C. Earley (Eds.), The International Handbook of Organizational Culture and Climate (pp. 143-163). Chichester: John Wiley \& Sons.

Schein, E. H. (1983). The Role of the Founder in Creating Organizational Culture. Organization Dynamics, Summer, 13-28. http://dx.doi.org/10.1016/0090-2616(83)90023-2

Schein, E. H. (1990). Organizational Culture. American Psychologist, 45(2), 109-119. http://dx.doi.org/10.1037/0003-066X.45.2.109

Schein, E. H. (2003). DEC is dead, long live DEC. The lasting legacy of Digital Equipment Corporation. San Francisco, CAL: Berrett-Koehler. - Dt.: Aufstieg und Fall von Digital Equipment Corporation. Eine Learning History oder: DEC ist tot - lang lebe DEC. Bergisch Gladbach.

Schein, E. H. (2004). Organizational Culture and Leadership (3rd ed.). New York: Wiley Publishers. - Dt. Organisationskultur. The Ed Schein Corporate Culture Survival Guide. Bergisch Gladbach.

Schein, E. H. (2005). Kultur von Organisationen. In Fatzer G. (Ed.), Gute Beratung von Organisationen. EHP, Bergisch Gladbach.

Schneider, B., \& Hall, D. T. (1972). Toward specifying the concept of work climate: a study of Roman Catholic Diocesan Priests. Journal of Applied Psychology, 56, 447-455. http://dx.doi.org/10.1037/h0033756

Statistical Yearbook. (2011). Federal Office of Statistics, Federation of Bosnia and Herzegovina, Sarajevo.

Wei, Y., \& Morgan, N. A. (2004). Supportiveness of Organizational Climate, market Orientation, and New Product Performance in Chinese Firms. Journal of Product Innovation Management, 21, 375-388. http://dx.doi.org/10.1111/j.0737-6782.2004.00092.x

\section{Notes}

Note 1. According to Mann-Whitney's non-parametric test.

Note 2. According to Kruskal Wallis non-parametric test. 